\title{
PREVALENCE OF WASTED, OVERWEIGHT AND OBESE CHILDREN BASED ON WORLD HEALTH ORGANISATION CUT-OFFS FOR BODY MASS INDEX, IN A URBAN SLUM
}

\author{
Sukanya Badami V1, Baragundi Mahesh C2 , Shashikala G. V3, Roopa Ankad B ${ }^{4}$, Umesh Ramadurga Y5
}

\section{HOW TO CITE THIS ARTICLE:}

Sukanya Badami V, Baragundi Mahesh C, Shashikala G. V, Roopa Ankad B, Umesh Ramadurga Y. "Prevalence of Wasted, Overweight and Obese Children Based on World Health Organization Cut-Offs for Body Mass Index, in a Urban Slum". Journal of Evolution of Medical and Dental Sciences 2014; Vol. 3, Issue 62, November 17;

Page: 13681-13685, DOI: 10.14260/jemds/2014/3828

\begin{abstract}
INTRODUCTION: BMI is a good indicator of levels of body fat, and it is known that having a BMI that is either too low or too high is associated with an increased risk of ill health during childhood as well as later in life. BMI is relatively quick and easy to calculate and as a result, is used for population surveys and by health professionals when assessing individual patients. OBJECTIVES: To assess the prevalence of wasted, overweight and obese children in an urban slum using WHO child growth standards BMI cut offs. MATERIALS AND METHODS: Study included 150 urban slum children of whom 77 were boys and 73 were girls. Anthropometric data in the form of height in cms and weight in kgs were collected by standard methods as reported by D. B. Jelliffe. BMI was calculated. Analysis of data was done according to WHO child growth standards. RESULTS: The prevalence of wasting was $25.97 \%$ in boys and $24.65 \%$ in girls. Among boys $1.29 \%$ were at risk of overweight, 2.59\% were overweight, $2.59 \%$ were obese. Among girls 5.47\% were at risk of overweight and $2.73 \%$ were obese. CONCLUSION: It can concluded from the study that undernutrition remains the main problem than overnutrition. However, the rapid changes in the dietary patterns and life styles occurring in many developing countries warrant close monitoring of overweight prevalence in children so that preventive measures can be taken in timely manner.
\end{abstract}

KEYWORDS: Overweight, Obese, Undernutrition, Children.

INTRODUCTION: The health of the people is the wealth of a country and nutrition is one of the most important pre requisite for good health. Poor nutritional status i.e. wasting is a major public health problem throughout developing world and is responsible for $35 \%$ of child deaths and $11 \%$ of total global disease burden. ${ }^{1}$ Child malnutrition remains a highly prevalent condition in low and middle income countries. ${ }^{2}$

Childhood obesity has emerged as a worldwide epidemic and has been a serious public health problem. ${ }^{3}$ Clinically significant obesity related morbidities are rare in children and are generally restricted to the severely obese. Such morbidities include the Pick Wickian syndrome, orthopedic disorders such as genu valgum and genu varum, respiratory disorders such as upper airway obstruction. ${ }^{4}$ The most prevalent immediate consequences for obese children are social isolation and peer problems. ${ }^{5}$

Of greater concern though, is the risk that over-weight during childhood will persist into adolescence and adulthood. ${ }^{6}$ This rising prevalence of obesity in children is a concern given the associated health risks later in life. In urban areas, over weight status and obesity are over three times as high as rural areas. ${ }^{7}$ To let obesity continue to develop uncontrolled is to accept the 


\section{ORIGINAL ARTICLE}

inevitability of an increased global burden of diabetes, cardiovascular disease and other chronic conditions. ${ }^{8}$

All through there are many accurate body fat measurement methods available to measure pediatric body composition in the research laboratory, ${ }^{9}$ there usage is limited due to high costs. The most frequently used tools in field settings in public health research are anthropometric based measurements such as the Body Mass Index (BMl).

$\mathrm{BMl}$ is most frequently used measure for assessing weather adults or children are obese, overweight, underweight or a healthy weight.

Hence the study was conducted to know the prevalence of wasted, overweight and obese children based on WHO cut offs for BMl in an urban slum area.

MATERIALS AND METHODS: Study sample consisted of a total of 150 children from an urban slum of whom 77 were boys and 73 were girls. The guidelines of institutional ethical committee were followed during the study. Ethical clearance was taken from the institutional ethical committee. Consent was taken from the parents / guardians of children who participated in the study.

The measurements were taken during morning hours by standard methods as reported by D.B. Jelliffe. ${ }^{10}$ Height was recorded with subject standing on the flat surface up to nearest $0.1 \mathrm{~cm}$. Length of children up to 2 years (or up to $85 \mathrm{cms}$ ) of age was measured with child on a horizontal board. Weight was recorded on a portable machine (spring type) up to nearest $0.1 \mathrm{~kg}$. The children were weighed with minimal clothing and bare feet. Body mass index (BMI) was calculated as body weight $(\mathrm{kg})$ divided by height squared $(\mathrm{m} 2)$.

Z score was calculated using WHO, BMI for age and sex, child growth standards. ${ }^{11}$ Interpretation was done using WHO training course on child growth assessment. Geneva manual 2008. ${ }^{12} \mathrm{Z}$ score 0 (median) and below -1 were taken as normal range. $\mathrm{Z}$ score below -2 was taken as wasted. Z score below-3 were taken as severely wasted. Z score above 1 was taken as possible risk of over- weight. $Z$ score above 2 were taken as over- weight. $Z$ score above 3 was taken as obese.

\section{RESULTS:}

\begin{tabular}{|c|c|c|c|c|c|c|c|c|}
\hline $\begin{array}{c}\text { Age in } \\
\text { months }\end{array}$ & $\begin{array}{c}\text { No. of } \\
\text { children }\end{array}$ & $\begin{array}{c}\text { Obese } \\
(\%)\end{array}$ & $\begin{array}{c}\text { Over } \\
\text { Weight } \\
\mathbf{( \% )}\end{array}$ & $\begin{array}{c}\text { Possible } \\
\text { Risk of } \\
\text { over- } \\
\text { weight } \\
\mathbf{( \% )}\end{array}$ & $\begin{array}{c}\text { Total } \\
\mathbf{( \% )}\end{array}$ & $\begin{array}{c}\text { Wasted } \\
\mathbf{( \% )}\end{array}$ & $\begin{array}{c}\text { Severely } \\
\text { Wasted } \\
\mathbf{( \% )}\end{array}$ & $\begin{array}{c}\text { Total } \\
(\%)\end{array}$ \\
\hline $0-12$ & 12 & $0(0)$ & $1(8.33)$ & $0(0)$ & $1(8.33)$ & $7(58.33)$ & $2(16.66)$ & $9(75)$ \\
\hline $13-24$ & 16 & $0(0)$ & $0(0)$ & $0(0)$ & $0(0)$ & $3(18.75)$ & $0(0)$ & $3(18.75)$ \\
\hline $25-36$ & 15 & $1(6.6)$ & $1(6.66)$ & $1(6.66)$ & $1(6.66)$ & $3(20)$ & $1(6.66)$ & $2(13.33)$ \\
\hline $37-48$ & 18 & $1(5.5)$ & $0(0)$ & $0(0)$ & $1(5.5)$ & $4(22.22)$ & $1(5.5)$ & $5(27.77)$ \\
\hline $49-60$ & 16 & $0(0)$ & $0(0)$ & $0(0)$ & $0(0)$ & $1(6.25)$ & $0(0)$ & $1(6.25)$ \\
\hline Total & 77 & $2(2.59)$ & $2(2.59)$ & $1(1.29)$ & $5(6.49)$ & $16(20.77)$ & $4(20.77)$ & $20(25.97)$ \\
\hline
\end{tabular}

Table 1: Age wise prevalence of nutritional status based on BMI in Boys 


\section{ORIGINAL ARTICLE}

\begin{tabular}{|c|c|c|c|c|c|c|c|c|}
\hline $\begin{array}{c}\text { Age in } \\
\text { months }\end{array}$ & $\begin{array}{c}\text { No. of } \\
\text { children }\end{array}$ & $\begin{array}{c}\text { Obese } \\
\mathbf{( \% )}\end{array}$ & $\begin{array}{c}\text { Over } \\
\text { Weight } \\
\mathbf{( \% )}\end{array}$ & $\begin{array}{c}\text { Possible } \\
\text { Risk of } \\
\text { over- } \\
\text { weight } \\
\mathbf{( \% )}\end{array}$ & $\begin{array}{c}\text { Total } \\
\mathbf{( \% )}\end{array}$ & $\begin{array}{c}\text { Wasted } \\
\mathbf{( \% )}\end{array}$ & $\begin{array}{c}\text { Severely } \\
\text { Wasted } \\
\mathbf{( \% )}\end{array}$ & $\begin{array}{c}\text { Total } \\
\mathbf{( \% )}\end{array}$ \\
\hline $0-12$ & 9 & $1(11.11)$ & $0(0)$ & $1(11.11)$ & $2(22.22)$ & $4(44.44)$ & $1(11.11)$ & $5(55.55)$ \\
\hline $13-24$ & 14 & $0(0)$ & $0(0)$ & $0(0)$ & $0(0)$ & $3(21.42)$ & $1(7.14)$ & $4(28.57)$ \\
\hline $25-36$ & 21 & $0(0)$ & $0(0)$ & $1(4.76)$ & $1(4.76)$ & $3(14.28)$ & $2(9.52)$ & $5(23.80)$ \\
\hline $37-48$ & 18 & $1(5.55)$ & $0(0)$ & $2(11.11)$ & $3(16.66)$ & $2(11.11)$ & $0(0)$ & $2(11.11)$ \\
\hline $49-60$ & 11 & $0(0)$ & $0(0)$ & $0(0)$ & $0(0)$ & $1(9.09)$ & $1(9.09)$ & $2(18.18)$ \\
\hline Total & $\mathbf{7 3}$ & $\mathbf{2 ( 2 . 7 3 )}$ & $\mathbf{0 ( 0 )}$ & $\mathbf{4 ( 5 . 4 7 )}$ & $\mathbf{6 ( 8 . 2 1 )}$ & $\mathbf{1 3 ( 1 7 . 8 0 )}$ & $\mathbf{5 ( 6 . 8 4 )}$ & $\mathbf{1 8 ( 2 4 . 6 5 )}$ \\
\hline
\end{tabular}

Table 2: Age wise prevalence of nutritional status based on BMI in Girls

Overall prevalence of under nutrition was $25.97 \%$ among boys and $24.65 \%$ among girls whereas overall prevalence of overnutrition was 6.49\% among boys and 8.21\% among girls. Under nutrition was more prevalent than over nutrition. Maximum number of wasted children were seen in 0-12 month's age group both in boys (75\%) and girls (55.55\%). Moderate wasting was more prevalent than severe wasting in both boys and girls. Obesity was seen in $2.59 \%$ of boys and $2.73 \%$ of girls. Over weight was seen in $2.59 \%$ boys and possible risk of over-weight was seen in $1.29 \%$ boys and $5.47 \%$ of girls. Maximum numbers of over nutrition children were seen during 25-36 months age in boys (20\%) and 37-48 months age in girls (16.66\%).

DISCUSSION: Nutritional status of slum children is worst amongst all the urban groups and even poorer than the rural average. ${ }^{13}$ Simultaneously obesity during childhood is a matter of concern. Several reports show increasing rates of obesity in developed countries, whereas the extent of the problem in developing countries remains unknown. ${ }^{6}$ In urban areas, overweight states and obesity are over three times as high as rural areas. ${ }^{7}$ Hence the present study was an attempt to know the prevalence of undernutrition and over nutrition among preschool children of an urban slum.

Comparable to present study Sayem Ahmed et al ${ }^{14}$ have reported underweight prevalence rate of $27.8 \%$ among under five children in Bangladesh. In other study, Bhandari TR et al in Nepal ${ }^{15}$ have reported wasting rate of $14.5 \%$ and severe wasting rate of $5 \%$ among children below five years based on BMI. The present study is in agreement with Khor GL et al ${ }^{16}$ study done in children under the age of five, who have reported wasting rate of $15.1 \%$ and $12.7 \%$ among boys and girls respectively and $6.3 \%$ and $4.5 \%$ severe wasting rates among boys and girls respectively. Maximum no of wasted children were seen in 0-12 months age group both in boys (75\%) and girls (55.55\%), which could be due faulty weaning habits.

Comparable to the present study, Khor $\mathrm{GL}^{16}$ et al in the study conducted in Malaysia in children below 5 years have reported $8.4 \%$ boys and $6.9 \%$ girls respectively at risk of overweight and $6.8 \%$ boys and $6 \%$ of girls respectively as overweight. National survey by Ministry of Health Malaysia and UNICEF in 1999-2000 has reported a overweight prevalence of 3.3\% in children under 5 years. ${ }^{17}$ A survey conducted in India during 1992-1993 among 25584 children has reported a overweight prevalence rate of 1.6.6 Study about prevalence and trends of overweight among pre-school children in developing countries by Mercedes de onis et $\mathrm{al}^{6}$ has reported that overall prevalence of overweight 


\section{ORIGINAL ARTICLE}

in under five children in developing countries is low (3.3\%) but 21 countries had prevalence of overweight $>5 \%$ and two countries had rates $>10 \%$. These data highlight the importance of closely monitoring future trends. For this purpose it is essential that survey data be analyzed systematically in a standard format to allow comparisons over times and across countries.

CONCLUSION: Over all wasting rates were higher than over weight rates in all studies including the present study. Hence the focus should be on improving under nutrition. However, the rapid changes in dietary patterns and life styles occurring in many developing countries warrant close monitoring of overweight prevalence in children so that preventive measures can be taken in a timely manner. ${ }^{18}$ Prevention of obesity requires that Governments, international agencies, consumers, industries trade, education system and the media, all join their hands together to promote healthy eating habits and encourage appropriate levels of physical activity among children.

\section{REFERENCES:}

1. Black RE, Allen LH, Bhutta ZA, Caufield LE, M de Onis, Ezzati $M$ et al. Maternal and child undernutrition: global and regional exposures and health consequences. Lancet 2008; 371 (9608): 243-60.

2. Caufield LE, M de Onis, Blossner M, Black RE. Undernutrition as an underlying cause of child deaths associated with diarrhea, pneumonia, malaria, and measles. Am J Clin Nutr 2004; 80 (1): 193-8.

3. Popkin BM, Doak CM. The obesity epidemic is a worldwide phenomenon. Nutr Rev 1998; 56: 106-114.

4. Must A. Morbidity and mortality associated with elevated body weight in children and adolescents. Am J Clin Nutr 1996; 63 (suppl): 518-25.

5. Dietz WH. Health consequences of obesity in youth: childhood predictors of adult disease. Pediatrics 1998; 101(suppl): 518-25.

6. Mercedes de Onis, Blossner M. Prevalence and trends of overweight among preschool children in developing countries. Am J Clin Nutr 2000; 72: 1032-9.

7. ^ a b c d e f “NFHS-3 Nutritional Status of Adults”. http://htev.org/india/nfhs/nfhs3/NFHS-3Nutritional-Status-of-adults.ppt. Retrieved 2009-11-26.

8. Dietz WH, Gortmaker SL. Preventing obesity in children and adolescents. Ann Rev Public Health 2001; 22: 337-53.

9. Leey SY, Gallagher D. Assessment methods in human body composition. Curr Opin Clin Nutr Metab Care 2008; 11: 566-572.

10. Jelliffe DB. The assessment of nutritional status of community. WHO monogram series 53; Geneva 1966. Available at whqlibdoc.who.int/monograph/WHO_MONO_\%\#_(part1).pdf. Accessed June 2012.

11. WHO (2006), WHO child growth standards, Length /Height-for-age, Weight-for-age, weight-forlength, weight-for-height, body mass index-for-age, Methods and development. Available at www.who.int/childgrowth/en/.Accessed june 2012.

12. World Health Organization. Training course on child growth assessment. Geneva, WHO 2008.

13. Ghosh S, Shah D. Nutritional problems in urban slum children. Indian pediatr 2004; 41 (7): 68296. 


\section{ORIGINAL ARTICLE}

14. Ahemad S, Hasan M, Ahemad W, Chowdhury AH. Socio-economic Inequity of Malnutrition among under- five Children and Women at Reproductive Age in Bangladesh. Journal of Nutrition and health 2013; 1 (1): 13-17.

15. Shah PU, Patel HJ. A study about prevalence of under nutrition among slum children of 0-60 months of age of Mehsana city. Shodh, Samiksha aur Mulyankan (International Research Journal) 2009; II (7): 84-85.

16. Khor GL, Noor Safiza MN, Jamalludin AB, Jamaiyah H, Geeta A, Kee CC et al. Nutritional status of children below five years in Malaysia: Anthropometric Analysis from the Third National Health and Morbidity Survey III (NHMS, 2006). Mal J Nutr 2009; 15 (2): 121-136.

17. Ministry of Health Malaysia (2000).Nutritional status children aged below 6 years in Malaysia. Unpublished report of a study conducted by Ministry of Health with cooperation of UNICEF in 1999-2000.

18. Popkin BM, Richards MK, Montiero CA. Stunting is associated with overweight in children of four nations that are undergoing the nutrition transition. J Nutr 1996; 126: 3009-16.

\section{AUTHORS:}

1. Sukanya Badami V.

2. Baragundi Mahesh C.

3. Shashikala G. V.

4. Roopa Ankad B.

5. Umesh Ramadurga Y.

\section{PARTICULARS OF CONTRIBUTORS:}

1. Assistant Professor, Department of Physiology, S. N. M. C, Bagalkot.

2. Associate Professor, Department of Microbiology, S. N. M. C, Bagalkot.

3. Assistant Professor, Department of Physiology, S. N. M. C, Bagalkot.

4. Assistant Professor, Department of Physiology, S. N. M. C, Bagalkot.
5. Assistant Professor, Department of Community Medicine, S. N. M. C, Bagalkot.

\section{NAME ADDRESS EMAIL ID OF THE CORRESPONDING AUTHOR:}

Dr. Sukanya Badami V, Assistant Professor, Department of Physiology, S. N. Medical College, Bagalkot-587102.

Email: sukanya_mahesh@rediffmail.com

Date of Submission: 08/10/2014. Date of Peer Review: 17/10/2014. Date of Acceptance: 12/11/2014. Date of Publishing: 15/11/2014. 